\title{
Assessment of Membrane Permeability in Primary Cultures of Neurons and Glia in Response to Osmotic Perturbation
}

\author{
S.V. Fischel and F. Medzihradsky \\ Departments of Biological Chemistry and Pharmacology, The University of \\ Michigan Medical School, Ann Arbor
}

In primary cultures of neurons and astrocytes from rat brain, the cellular contents of $\mathrm{K}^{+}$and $\mathrm{Na}^{+}$were used to assess plasma membrane permeability in response to osmotic shock. In contrast to trypan blue exclusion, the measure of ionic content reflected both transient and permanent membrane damage, and was also applicable to aggregates of cells. In steady state, the neurons and glia exhibited a $\mathrm{K}^{+}$to $\mathrm{Na}^{+}$ratio of 3-5, and the mean cellular contents $\left(\mu \mathrm{Eq} / \mathrm{mg}\right.$ protein) of $\mathrm{K}^{+}$ and $\mathrm{Na}^{+}$were 0.72 and 0.17 for astrocytes and 0.78 and 0.23 for neurons. Both hypo- and hypertonicity resulted in marked efflux of cell $\mathrm{K}^{+}$, but elevation of cellular $\mathrm{Na}^{+}$occurred only under severe hypertonic conditions. Relative to neurons, astrocytes displayed considerably higher resistence to osmotic shock. During subsequent isotonic incubation, these cells were able to completely recover from transient membrane damage caused by a 10-min exposure to fourfold hypertonicity. Permanent changes in glial permeability were obtained only after a 20 -min hypertonic shock. In contrast, 5 min hypertonic treatment of neurons decreased the ratio of cellular $\mathrm{K}^{+}$to $\mathrm{Na}^{+}$from 4.5 to 1 . This ratio was restored twofold by isotonic incubation, but decreased permanently to below 1 after $10 \mathrm{~min}$ of hypertonic shock. The results describe marked differences in the osmotic fragility of neurons and glia and demonstrate that the determination of cellular $\mathrm{K}^{+}$and $\mathrm{Na}^{+}$ provides a sensitive and accurate indicator of membrane permeability in neural cells propagated as surface-growing cultures. The approach has wide-ranging applicability.

Key words: astrocytes, cell membrane, cell viability, dye exclusion test, glia, hypertonicity, hypotonicity, membrane permeability, neurons, potassium, sodium

\section{INTRODUCTION}

The assessment of cell viability is an essential step in studies using isolated cells. Reflecting the specific focus in a given investigation, the index of cell viability

Steven V. Fischel's present address is Department of Neuroscience, Children's Hospital Medical Center, and Department of Neuropathology, Harvard Medical School, Boston, MA 02115.

Address reprint requests to Fedor Medzihradsky, Department of Biological Chemistry, The University of Michigan Medical School, Ann Arbor, MI 48109.

Received April 2, 1984; accepted July 2, 1984.

(C) 1985 Alan R. Liss, Inc. 
has received different interpretations, and thus various methodological approaches have been applied to test this cellular parameter [Malinen and Perry, 1967]. A widely used criterion for cell viability, the dye exclusion test, actually reflects membrane permeability. It is based on the premise that the plasma membrane of viable cells is impermeable to compounds of fairly high molecular weight such as trypan blue or eosin [Hanks and Wallace, 1958]. We have previously compared the responses of several measures of cell membrane permeability, including trypan blue exclusion, release of cytoplasmic lactate dehydrogenase, and the cellular contents of $\mathrm{K}^{+}$and $\mathrm{Na}^{+}$, to osmotic and chemical perturbations in normal and malignant cells in vitro [Medzihradsky and Marks, 1975]. The results showed cell staining by trypan blue to be a relatively sluggish measure of cell permeability, and have suggested the use of the cellular concentrations of $\mathrm{K}^{+}$and $\mathrm{Na}^{+}$as sensitive indicators of plasma membrane integrity. The usefulness of the latter parameter as a stringent criterion to detect changes in cell permeability has subsequently been emphasized [Baur et al, 1975]. In recognizing the disadvantages of the trypan blue exclusion test, e.g., its inherent variability and subjectiveness, other studies have suggested the use of electronic particle sizing [Atallah and Johnson, 1981] or flow-cytometric analysis of the uptake of fluorescent probes [Lalande et al, 1981] as methods to assess cytoplasmic membrane permeability.

The most commonly used procedure to assess the viability of cells in culture is the dye exclusion test using trypan blue [Patterson, 1979]. However, in the course of our work with neurons and glia from rat brain, this method proved to be impractical when applied to neurons grown in primary culture. The soma of these cells formed tightly bound aggregates, the dispersion of which prior to the dye exclusion test invariably caused membrane damage. In view of this difficulty, and considering our previous experience with trypan blue as an index of cell viability, we have in the present study measured the changes of cellular $\mathrm{K}^{+}$and $\mathrm{Na}^{+}$in substrate-adherent neurons and glia in response to osmotic perturbation, in order to evaluate this methodological approach of assessing the plasma membrane permeability of these two types of neural cells.

\section{MATERIALS AND METHODS \\ Primary Cultures of Neurons}

With minor modifications, the procedure of Yavin and Yavin [1974, 1980; Yavin et al, 1981] was followed. Briefly, whole cerebra from fetal rats (Sprague-Dawley, 16 days gestation) in Eagle's Basal Medium-Earle's formulation (BME) supplemented with $30 \%$ fetal bovine serum, were disrupted mechanically by means of a $10-\mathrm{ml}$ syringe with a 14-gauge needle, followed by passage through a Nitex mesh with a pore size of $110 \mu \mathrm{m}$. The resulting cell suspension was centrifuged at $200 \times \mathrm{g}$ for 2 min at room temperature, and the supernatant containing cell debris was discarded. The pellet was resuspended in a hormone-supplemented, serum-free media consisting of BME with $0.6 \%$ glucose, $10 \mu \mathrm{g} / \mathrm{ml}$ insulin, $10^{-8} \mathrm{M}$ hydrocortisone, $5 \mu \mathrm{g} / \mathrm{ml}$ transferrin, $10 \mathrm{ng} / \mathrm{ml}$ glycol-L-histidyl-L-lysine, and $10 \mathrm{ng} / \mathrm{ml}$ somatostatin. After a second centrifugation, the pellet was suspended in the serum-free medium to a concentration of $4 \times 10^{6}$ cells $/ \mathrm{ml}$. Cells were plated as $1.5-\mathrm{ml}$ aliquots in $35-\mathrm{mm}$ polystyrene tissue culture dishes, previously coated with $5 \mu \mathrm{g} / \mathrm{ml}$ poly-L-lysine in water and rinsed with Hank's Balanced Salt Solution. The cultures were incubated at 
$37^{\circ} \mathrm{C}$ in a humidified atmosphere of $5 \% \mathrm{CO}_{2}$ and $95 \%$ air without additional changes of media. Fresh medium, amounting to one-third of the original volume, was added after 7 days. These cultures were assayed between 7 and 10 days in culture.

\section{Primary Cultures of Astrocytes.}

With some modifications, the cells were grown according to the procedure of Cummins and Glover [1978], which is based on the method introduced earlier [Booher and Sensenbrenner, 1972]. Cerebra of 3- to 5-day-old Sprague-Dawley rats were removed, cleaned under sterile conditions, and minced in $2 \mathrm{ml}$ of BME, supplemented with $10 \%$ calf serum, $50 \mathrm{U} / \mathrm{ml}$ penicillin, and $50 \mu \mathrm{g} / \mathrm{ml}$ streptomycin. This suspension was transferred to a sterile 50-ml glass centrifuge tube in $5 \mathrm{ml}$ of media, then disrupted for $50 \mathrm{sec}$ on a vortex mixer, and the volume increased to approximately $12 \mathrm{ml}$ with medium [Bullaro and Brookman, 1976]. After the cells had settled for $20 \mathrm{~min}$, the supernatant was aspirated off and the cells were gently sieved through a $110-\mu \mathrm{m}$ Nitex mesh followed by a second pass through a 53- $\mu \mathrm{m}$ Nitex mesh. These modifications [Hertz et al, 1978] eliminated the need for trypsin in dissociating the tissue. The resulting single-cell suspension was diluted to volume $(30-35 \mathrm{ml}$ of media per cerebrum) and plated on untreated sterile polystyrene tissue culture dishes ( $3 \mathrm{ml}$ per $60 \mathrm{~mm}$ diameter dish). Culture medium was changed 24 to $48 \mathrm{hr}$ later and every 3 to 4 days thereafter. The cultures were maintained at $37^{\circ} \mathrm{C}$ in a humidified atmosphere of $5 \% \mathrm{CO}_{2}$ and $95 \%$ air. Under these conditions, cells attained confluency after approximately 10 days in culture, and were assayed shortly thereafter. In several experiments, the cells were used after 2-3 weeks in culture. In these cells, the responses assessed in this study were not significantly different.

\section{Characterization of Cell Cultures}

The cells were evaluated by phase-contrast microscopy, histochemical techniques, and by the determination of enzyme markers. Briefly, Bodian silver stain [Humason, 1967] and Cajal's gold sublimate [Thompson and Hunt, 1966] were applied to characterize neurons and astrocytes, respectively. The neuronal and glial isozymes of enolase were separated in $100,000 \times \mathrm{g}$ cell supernatants by fractionation over DE-52 microcolumns, and assayed for activity by following the formation of phosphoenolpyruvate at $340 \mathrm{~nm}$ [Scarna et al, 1980]. Isozyme activities were expressed as the percent of total enolase activity. The activity of oligodendroglial marker, 2', 3'-cyclic nucleotide 3'-phosphohydrolase, was determined with some modifications as described [Prohaska et al, 1973]. The cells were rinsed three times and frozen in double-distilled water until used [McCarthy and DeVellis, 1980]. Upon thawing, the samples were solublized with Tris-buffered deoxycholate and assayed at $30^{\circ} \mathrm{C}$ for the ability to cleave $2^{\prime}, 3^{\prime}-\mathrm{cAMP}$. The product of this reaction was completely hydrolyzed with alkaline phosphatase to yield adenosine and inorganic phosphate. Subsequently, the samples were deproteinized with perchloric acid and assayed colorimetrically for phosphate [Medzihradsky et al, 1971].

\section{Determination of Protein}

The method of Lowry et al [1951] was applied using crystallized, lyophilized bovine serum albumin as the standard. The latter was prepared using the same buffer medium present in the biological samples being tested, unless it was demonstrated 
experimentally that the components of that medium did not interfere with the protein determination [Peterson, 1979].

\section{Determination of Cellular Potassium and Sodium}

Cells growing in $60-\mathrm{mm}$ or $35-\mathrm{mm}$ diameter culture dishes were washed four times with ice-cold $0.28 \mathrm{M}$ sucrose adjusted to $\mathrm{pH} 7.4$ with Tris base. The cellular material from one dish was scraped and transferred with $5 \mathrm{ml}$ of standardized $\mathrm{LiNO}_{3}$ solution $(15 \mathrm{uEq} / \mathrm{l})$ into 8-ml polypropylene tubes. After sonication for $20 \mathrm{sec}$ (Bronson sonifier with microtip, power output 6), two $100-\mu 1$ aliquots were removed for protein determination, and $50 \mu \mathrm{l}$ of concentrated $\mathrm{HNO}_{3}$ were added to give a final concentration of $0.1 \mathrm{~N}$. The samples were digested at room temperature overnight. Alternatively, cell digestion can be carried out for $2 \mathrm{hr}$ at $70^{\circ} \mathrm{C}$. If the ion levels were not measured at this time, the samples were stored at $-70^{\circ} \mathrm{C}$.

Before the ion content of the samples was assessed, any solid material remaining in the samples tubes was removed by centrifugation at $15,000 \times \mathrm{g}$ for $10 \mathrm{~min}$. Sodium and potassium levels were determined using an IL flame photometer (model 143, Instrumentation Laboratories, Inc., Lexington, MA). The instrument was calibrated with a standardized solution of $\mathrm{NaCl}$ and $\mathrm{KCl}$ in $\mathrm{LiNO}_{3}$. Results were expressed as microequivalents ion $/ \mathrm{mg}$ protein, or as the ratio of cellular $\mathrm{K}^{+}$to $\mathrm{Na}^{+}$.

In order to test the sensitivity of this technique, the cells in culture were rinsed twice and covered with a buffer medium which in its composition (mM) closely resembled cerebrospinal fluid [Katzman, 1976]: $\mathrm{NaCl}, 125 ; \mathrm{KCl}, 1.8 ; \mathrm{CaCl}_{2}, 1.3$; $\mathrm{MgSO}_{4}, 1.2 ; \mathrm{KH}_{2} \mathrm{PO}_{4}, 1.2 ; \mathrm{NaHCO}_{3}, 25 ;$ glucose, 10 . The osmolarity of the medium was $326 \mathrm{mOsm}$, and the $\mathrm{pH}$ of the medium was adjusted to 7.4 with $\mathrm{CO}_{2}$. The cells were incubated at $37^{\circ} \mathrm{C}$ under $95 \%$ air $-5 \% \mathrm{CO}_{2}$, and were exposed to osmotic shock for $15 \mathrm{~min}$. Osmolarity was increased by the addition of sucrose to the buffer medium, and was decreased by lowering the concentration of all the buffer constituents proportionately. Alternatively, the osmolarity was increased fourfold by the addition of sucrose, and the incubation time was varied. Subsequently, the cells were rinsed with isotonic buffer and either incubated for an additional $15 \mathrm{~min}$ in this medium or processed directly for the determination of cellular $\mathrm{K}^{+}$and $\mathrm{Na}^{+}$and/or trypan blue exclusion. The osmolarity of all buffers was determined with a Fiske osmometer.

\section{Trypan Blue Exclusion}

The cells were rinsed with the artificial cerebrospinal fluid from which $\mathrm{Ca}^{++}$ and $\mathrm{Mg}^{++}$were omitted, and were incubated for $1 \mathrm{~min}$ at room temperature with $0.25 \%$ trypsin in the $\mathrm{Ca}^{++}, \mathrm{Mg}^{++}$-free buffer. The latter medium was replaced with $2 \mathrm{ml}$ of $0.04 \%$ trypan blue in the $\mathrm{Ca}^{++}, \mathrm{Mg}^{++}$-free buffer and incubated for an additional $10 \mathrm{~min}$ at $37^{\circ} \mathrm{C}$ under $95 \%$ air $-5 \% \mathrm{CO}_{2}$ [Patterson, 1979]. At this point, the cells had sufficiently retracted from the culture dish to be gently suspended in the trypan blue solution by trituration, and were subsequently counted in a haemocytometer under a phase microscope. Results were expressed as percent cells excluding the dye.

\section{RESULTS}

\section{Characterization of the Cells in Culture}

The flat, polygonal shape of the astrocytes was strikingly absent in the neuronal cultures in which cell bodies and their interconnecting processes were visible (Fig. 1). 
The use of histochemical procedures confirmed the observations made by phase microscopy on the purity and preserved morphology of the cells. Neurons were visualized by Bodian silver stain (and counterstained with gallocyanine), while astrocytes were identified with Cajal's gold sublimate. Accordingly, Bodian stain was ineffective in the astrocytic cultures, while in the neuronal preparations no blue staining was observed in response to Cajal's gold sublimate. The pertinence of the histochemical characterization was further demonstrated in mixed neuron-glia cultures in which, again, the morphological evidence was supported by appropriate responses to staining (not shown). The distribution of enzyme markers in the neuronal and glial preparations was also assessed. Enolase is a dimer composed of subunits that are either neuronal or glial in origin [Schmechel et al, 1978]. Immature neurons contain the glial isozyme but in the course of development acquire the neuron-specific form [Marangos et al, 1980]. When compared to the total enolase activity present in the cultured astrocytes after 12 days in culture, these cells contained less than $5 \%$ of the neuronal subunit. In neuronal cultures, this value was $21 \%$, while in rat brains of a correlative age (i.e., rats that had been allowed to continue to grow for the same amount of time as the cells had been in culture) the relative content of the neuronal subunit of enolase was $34 \%$. While this distribution reflects neuronal presence, the numerical values do not serve as quantitative measures for the purity of cultures. Neuronal enolase is developmentally regulated and correlates with the degree of cellular differentiation [Marangos et al, 1980]. Furthermore, brain also contains a hybrid isozyme of enolase [Marangos et al, 1978].

\section{Response to Osmotic Shock}

Initial experiments focused on the feasibility of using the determination of cellular $\mathrm{K}^{+}$and $\mathrm{Na}^{+}$to monitor membrane permeability in surface-growing cultures. Rinsing the astrocytic cultures four to five times with ice-cold isotonic sucrose was sufficient to remove extracellular $\mathrm{Na}^{+}$with minimum depletion of the intracellular content of $\mathrm{K}^{+}$(Fig. 2). Similar washout curves were obtained for the neuronal cultures. The mean values for the cellular contents of $\mathrm{K}^{+}$and $\mathrm{Na}^{+}$determined in this study were (in $\mu \mathrm{Eq} / \mathrm{mg}$ protein) $0.72 \pm 0.12$ and $0.17 \pm 0.03$ (S.D., at $\mathbf{n}=11$ ) for astrocytes, and $0.78 \pm 0.08$ and $0.23 \pm 0.04$ (S.D., at $n=6$ ) for neurons.

The sensitivity of the cellular concentrations of $\mathrm{K}^{+}$and $\mathrm{Na}^{+}$as indicators of membrane permeability was tested by exposing the cells to osmotic shock. As determined with astrocytes (Fig. 3), hypotonic shock resulted in a decreased $\mathrm{K}^{+}$to $\mathrm{Na}^{+}$ratio, primarily due to a loss of intracellular potassium. As a result of hypertonic shock, the ratio of $\mathrm{K}^{+}$to $\mathrm{Na}^{+}$was again reduced, but in this case the decrease was also due to an elevated influx of $\mathrm{Na}^{+}$, particularly noticeable under severe hypertonia (Fig. 4). Up to a twofold change in osmolarity, resulting in either hypo- or hypertonia, caused similar changes in the cellular $\mathrm{K}^{+} / \mathrm{Na}^{+}$in astrocytes (Fig. 3). With increasing severity of the osmotic shock, the relative damage caused by hypertonic incubations became more pronounced. The value for the cellular $\mathrm{K}^{+} / \mathrm{Na}^{+}$at fourfold hypo- and hypertonicity was 2 and 1 , respectively. Relative to neurons, astrocytes exhibited markedly high resistence to hypertonicity (Figs. 5A, 4A). After a 5-min exposure to the osmotic shock, the ratio $\mathrm{K}^{+} / \mathrm{Na}^{+}$in neurons fell from 4.0 to about 1 , caused by the massive efflux of $\mathrm{K}^{+}$in addition to a twofold rise in cellular $\mathrm{Na}^{+}$(Fig. 5A). By comparison, at the 5-min timepoint $\mathrm{K}^{+} / \mathrm{Na}^{+}$in astrocytes was still higher than 2.5 , and cell $\mathrm{Na}^{+}$was virtually unchanged (Fig. 4A). The differential responses of the 

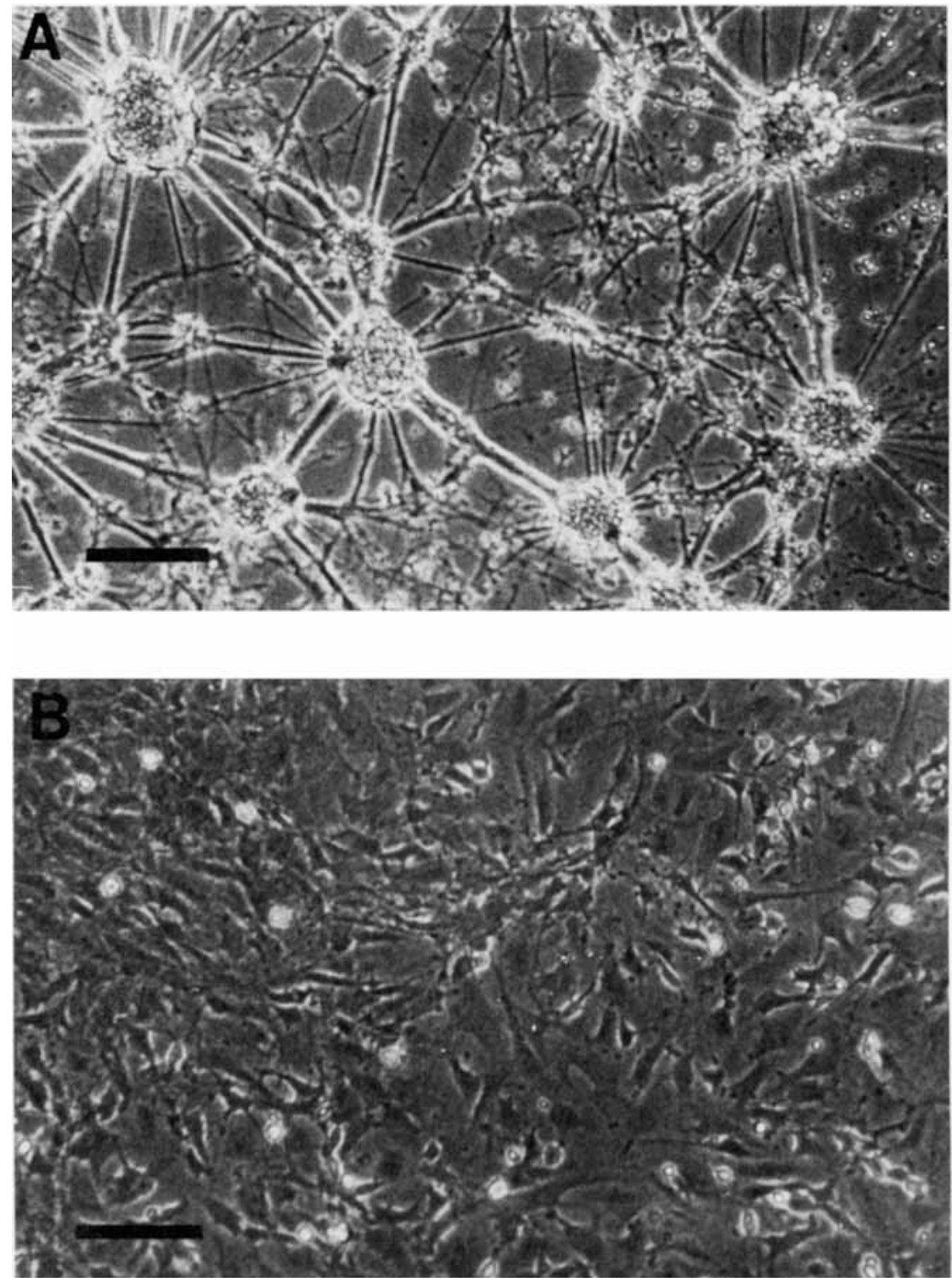

Fig. 1. Phase contrast photomicrographs of primary cultures of neurons and glia. Shown are neurons (A) and astrocytes (B) after growth for 7 to 10 days in vitro as described under "Materials and Methods." The bar at the bottom-left of each photograph represents $100 \mu \mathrm{m}$.

two cell types were further pronounced at $10 \mathrm{~min}$ of hypertonic treatment. At this time, the neuronal contents of $\mathrm{K}^{+}$and $\mathrm{Na}^{+}$were already approaching their maximal reversal induced by the perturbation. On the other hand, the corresponding glial ratio of $\mathrm{K}^{+} / \mathrm{Na}^{+}$was still approximately 2 .

\section{Recovery Subsequent to Osmotic Shock}

The extent of membrane damage caused by the osmotic shock was reflected in the ability of the cells to re-establish their original ratio of $\mathrm{K}^{+}$and $\mathrm{Na}^{+}$during the 

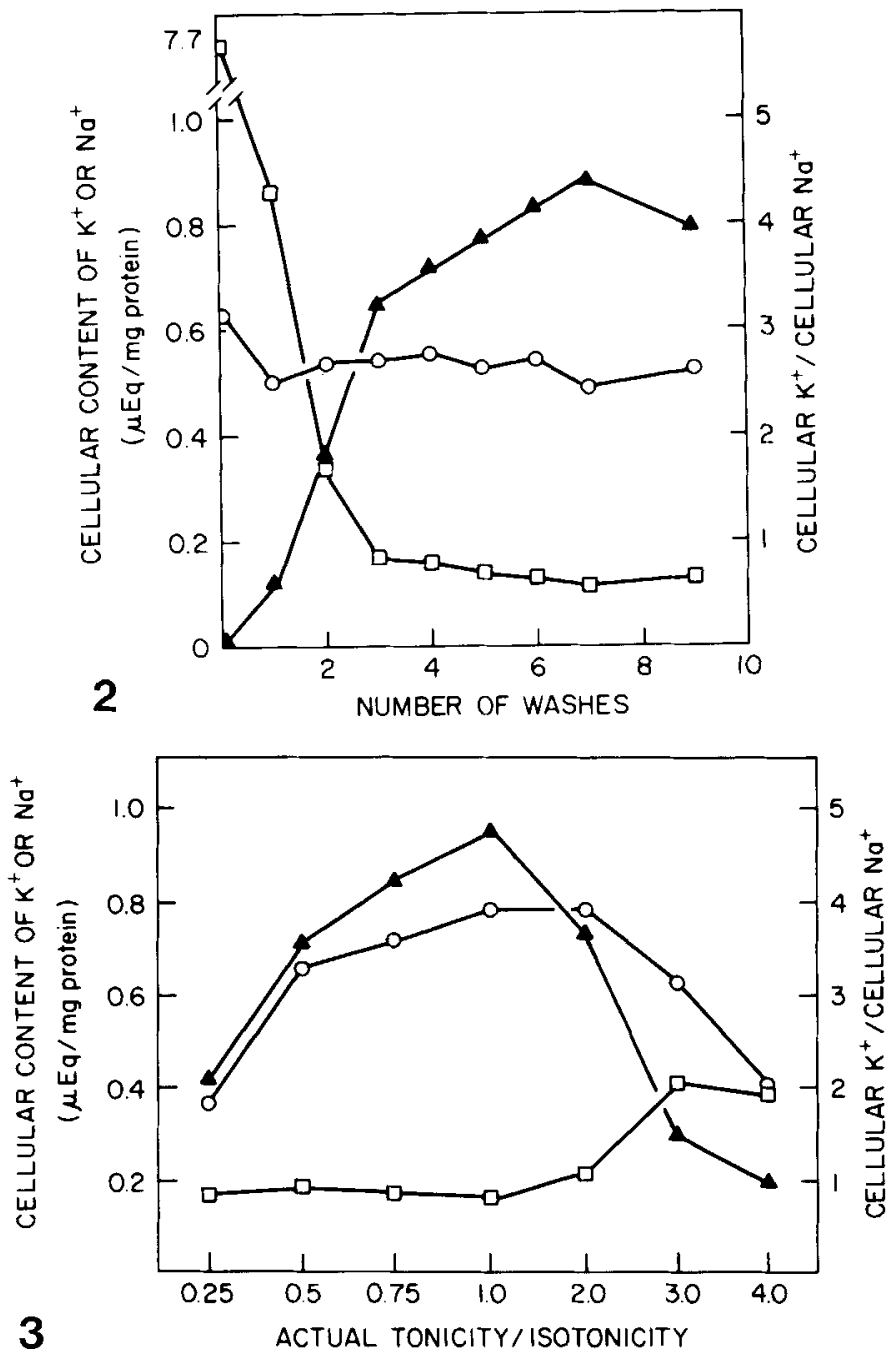

Fig. 2. Effect of washing on the potassium and sodium content of astrocytes in culture. Monolayer cultures of astrocytes were rinsed the indicated number of times with ice-cold $0.28 \mathrm{M}$ sucrose, adjusted to $\mathrm{pH} 7.4$ with Tris base, and the cellular contents of $\mathrm{K}^{+}(\mathrm{O})$ and $\mathrm{Na}^{+}(\square)$ were determined as described under "Materials and Methods." Also depicted are the ratios of cellular $\mathrm{K}^{+}$to $\mathrm{Na}^{+}(\mathbf{\Delta})$. Shown are average values obtained in two experiments, each carried out with duplicate samples.

Fig. 3. Effect of altered tonicity on the potassium and sodium content of astrocytes in culture. The tonicity of the artificial CSF buffer was increased or decreased as described under "Materials and Methods." Monolayer cultures of astrocytes were incubated with buffers of the indicated tonicity for 15 min, rinsed four times with isotonic sucrose, and processed to determine the cellular contents of $\mathrm{K}^{+}$ $(\bigcirc)$ and $\mathrm{Na}^{+}(\square)$, and their ratio $(\boldsymbol{\Delta})$. Shown are averages obtained in a representative experiment run in triplicate. The experiment was carried out three times. 


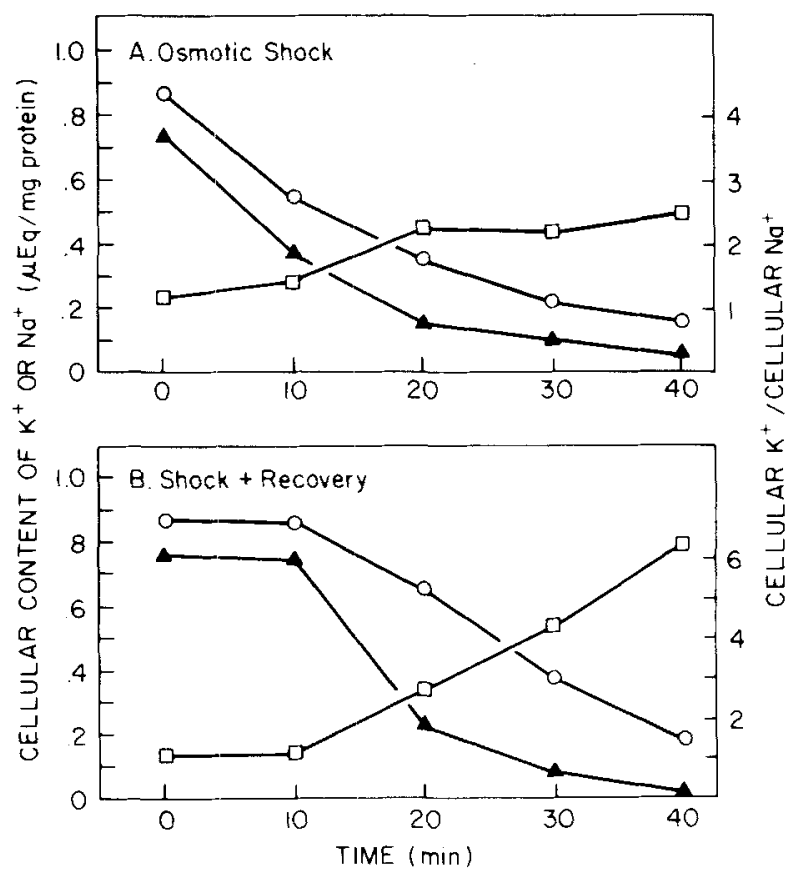

Fig. 4. Cellular contents of potassium and sodium in cultured astrocytes in response to osmotic shock and subsequent recovery. Monolayers of cells were exposed to a fourfold hypertonic CSF buffer medium for various lengths of time as indicated. The concentrations of cellular $\mathrm{K}^{+}(O)$ and $\mathrm{Na}^{+}(\square)$ were determined either immediately after osmotic shock (A), or subsequent to an additional 15 min incubation in isotonic medium (B). Prior to the analysis by flame photometry, the cells were washed four times with buffered isotonic sucrose. Also plotted are the ratios of cellular $\mathrm{K}^{+}$to $\mathrm{Na}^{+}(\boldsymbol{\Delta})$. The results represent the averages of triplicate determinations within a representative experiment. The experiment was carried out twice.

course of a subsequent incubation in isotonic buffer. This approach was applied in order to distinguish between reversible and permanent changes in membrane permeability. Again, the marked difference in osmotic fragility of neurons and astrocytes became apparent. As indicated by the values of cellular $\mathrm{K}^{+} / \mathrm{Na}^{+}$, after an initial 5min and 10-min hypertonic shock, neurons exhibited a twofold recovery during the subsequent isotonic incubation. Still, the extent of irreversible changes was considerable. After 10 min of osmotic insult, the value of the neuronal $\mathrm{K}^{+} / \mathrm{Na}^{+}$was 1 despite recovery (Fig. 5B). On the other hand, under comparable conditions astrocytes totally recovered from the osmotic shock (Fig. 4B). The glial $\mathrm{K}^{+}$to $\mathrm{Na}^{+}$ratio fell irreversibly below 1 only after $30 \mathrm{~min}$ of exposure to the fourfold hypertonic medium.

Since it was possible to prepare a unicellular suspension of astrocytes, these cultures were used to compare the response of trypan blue exclusion test to the changes in cellular contents of $\mathrm{K}^{+}$and $\mathrm{Na}^{+}$in response to osmotic manipulations. Cell viability indicated by staining correlated with the irreversible decrease in the $\mathrm{K}^{+}$ to $\mathrm{Na}^{+}$ratio, i.e., with shock-induced changes in ionic content that did not recover during the subsequent exposure to isotonic conditions (Fig. 6).

\section{DISCUSSION}

An intact cytoplasmic rnembrane is essential for the normal functioning of cells. Membrane damage will be reflected in altered permeability for various solutes. 


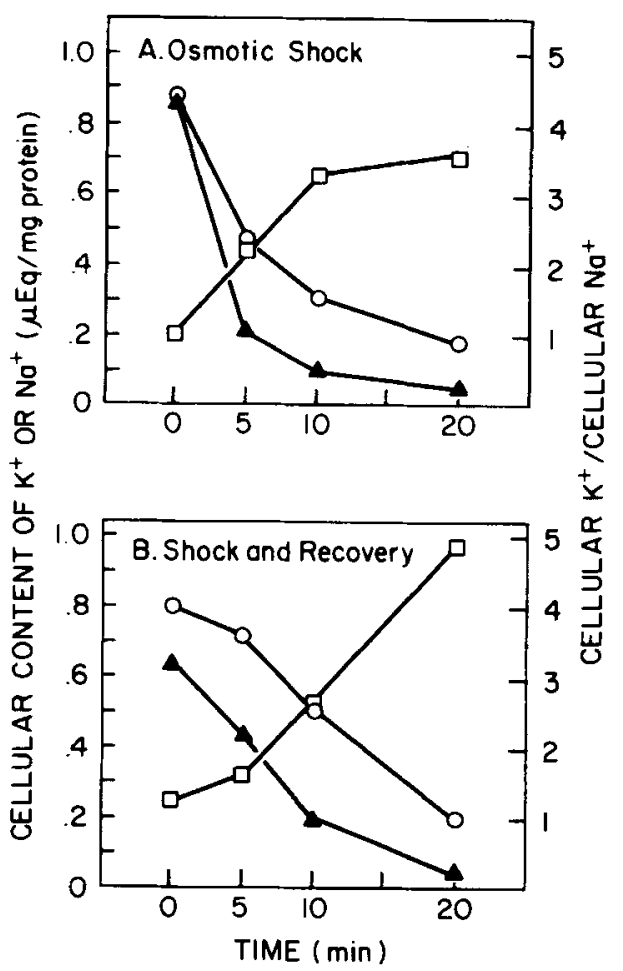

Fig. 5. Cellular content of potassium and sodium in primary cultures of neurons in response to osmotic shock and subsequent recovery. In all details these experiments with primary cultures of neurons were carried out as described for astrocytes in the legend to Figure 4. Plotted on the abscissa is the time of exposure to fourfold hypertonic conditions, while the ordinate depicts either the cellular contents of $\mathrm{K}^{+}$ (O) and $\mathrm{Na}^{+}(\square)$, or the ratio of $\mathrm{K}^{+} / \mathrm{Na}^{+}(\mathbf{A})$. A and B show data obtained immediately after the osmotic shock and subsequent to an additional 15-min incubation in isotonic medium, respectively. Shown are the averages of triplicate determinations obtained within a representative experiment. The experiment was carried out twice.

Whether or not a plasma membrane will exclude a relatively high molecular weight compound such as trypan blue depends on the extent of membrane damage. Subtle changes in membrane permeability have numerous consequences at the cytoplasmic and nuclear levels [Thelestam and Mollby, 1980], and are likely to affect the cellular transport of a large number of biologically important compounds of low molecular weights. However, such limited perturbations would not necessarily be reflected in the cellular exclusion or uptake of a structurally bulky compound with a molecular weight of approximately 900 , such as trypan blue. After comparing various measures of viability in isolated cells, including dye exclusion [Medzihradsky and Marks, 1975], we have routinely used the cellular contents of $\mathrm{K}^{+}$and $\mathrm{Na}^{+}$as indicators of plasma membrane integrity/cell viability in the course of our studies on the mechanisms of cellular drug transport [Medzihradsky, 1979, 1982], and in developing procedures for cell isolation [Medzihradsky et al, 1974; Medzihradsky and Metcalfe, 1975; Cullen and Medzihradsky, 1980]. In a detailed study, the cellular concentrations of $\mathrm{K}^{+}$and $\mathrm{Na}^{+}$were again described as the most sensitive criterion of cell viability [Baur et al, 1975]. In view of our experience in applying this criterion to unicellular 


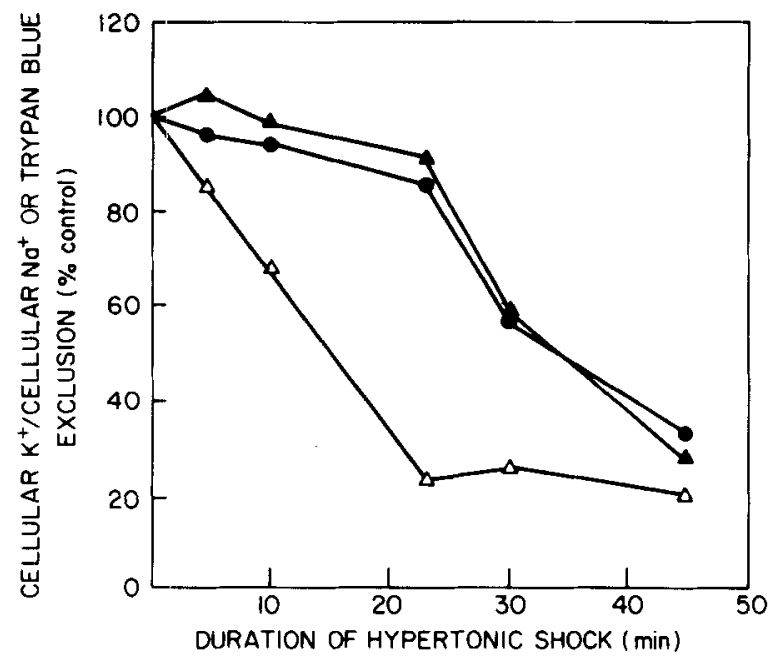

Fig. 6. Assessment of hypertonic shock in cultured astrocytes by the ratio of cellular $\mathrm{K}^{+} / \mathrm{Na}^{+}$and by Irypan blue exclusion. Astrocytes were exposed to hypertonic CSF buffer, made fourfold normal osmolarity by the addition of sucrose, for the lengths of time indicated. The cells were either assayed directly, or were incubated for an additional $15 \mathrm{~min}$ in isotonic CSF medium. The cellular contents of $\mathrm{K}^{+}$and $\mathrm{Na}^{+}$were determined and trypan blue uptake was carried out as described under "Materials and Methods." Plotted are the ratio of cellular $\mathrm{K}^{+}$to $\mathrm{Na}^{+}$, immediately following the osmotic shock $(\triangle)$, as well as $\mathrm{K}^{+} / \mathrm{Na}^{+}(\boldsymbol{\Delta})$ and trypan blue exclusion $(\mathbf{O})$ after the isotonic recovery. Shown are the averages of data obtained in two experiments carried out in triplicate.

suspensions, and considering our work on receptor and transport mechanisms in neurons and glia in primary cultures, it was of interest to assess its usefulness to indicate membrane permeability in these surface-growing cells.

The primary cultures used in this study showed a preserved morphology of both cell types. A number of cellular markers were used to ascertain the purity of the two preparations. Both neurons and glia maintained at least a threefold higher concentration of $\mathrm{K}^{+}$relative to $\mathrm{Na}^{+}$. Considering the different procedures used for cell isolation and subsequent handling, it is difficult to compare absolute values for the cellular contents of $\mathrm{K}^{+}$and $\mathrm{Na}^{+}$, particularly when expressed on the basis of cellular protein. In a recent study with astrocytic cultures similar to ours, cellular $\mathrm{K}^{+} / \mathrm{Na}^{+}$ was 2.8 and 4.4 at extracellular $\mathrm{K}^{+}$of $3.0 \mathrm{mM}$ and $5.4 \mathrm{mM}$ [Walz and Hertz, 1983]. Thus our results, obtained at $1.8 \mathrm{mM} \mathrm{K}^{+}$in the medium, compare quite favorably. In cultures of astrocytes from hamster and rat [Lees and Shein, 1970], the values for potassium and sodium were quite similar to those obtained in this paper. In another report, the ratio of cellular $\mathrm{K}^{+}$to $\mathrm{Na}^{+}$in cultured rat astrocytes was 4.55 [Gill et al, 1974], a value in close agreement with that measured in our study. However, in neither of these investigations were cellular contents of $\mathrm{K}^{+}$and $\mathrm{Na}^{+}$used as indicators of cell viability, nor were these parameters determined in response to membrane perturbations by osmotic means.

In comparing the responses of neurons and glia to osmotic shock, it is of interest to focus on the cellular contents of $\mathrm{K}^{+}$and $\mathrm{Na}^{+}$immediately after the insult, and subsequent to a recovery period under isotonic conditions. The respective values of the ions reflect transient and permanent changes in membrane permeability. The contrasting responses of neurons and glia are illustrated by their ionic contents 
subsequent to a 10-min exposure to hypertonic conditions. While the value of $\mathrm{K}^{+} /$ $\mathrm{Na}^{+}$in neurons decreased ninefold with little recovery during isotonic incubation, the twofold decrease of $\mathrm{K}^{+} / \mathrm{Na}^{+}$in astrocytes was completely restored by isotonic treatment (Figs. 4,5). Furthermore, 5-min hypertonia caused minimal changes of permeability in astrocytes, but induced permanent membrane damage in neurons. Glial permeability was irreversibly altered only after 20 min of osmotic perturbation.

The results of this study reveal marked differences in the membrane permeability of neurons and glia in response to osmotic perturbations. The findings also show that the dynamics of membrane permeability in primary cultures of these cells are reflected by corresponding changes in the cellular contents of $\mathrm{K}^{+}$and $\mathrm{Na}^{+}$. This parameter thus proved to be a sensitive indicator of both transient and permanent changes of plasma membrane integrity. On the other hand, the trypan blue exclusion test had limited applicability and, in astrocytes, correlated with irreversible membrane damage. The utilization of a sensitive, rapidly responding indicator of neural cell permeability is wide ranging. For example, the approach described in this study can be used to quantitate the distribution of cellular $\mathrm{K}^{+}$and $\mathrm{Na}^{+}$following membrane depolarization in vitro and to study neuronal and glial permeability underlying tissue swelling in in vitro models of brain edema [Kempski et al, 1983]. Furthermore, the permeability indicator can serve as a stringent criterion to test for "leakiness" of the plasma membrane in experiments investigating the transport of small molecules, compounds much below the size of vital stains such as trypan blue.

\section{ACKNOWLEDGMENTS}

We thank Dr. R.A. Glover for his valuable assistance in applying the histochemical methods. The work was supported in part by USPHS grant DA 00254 .

\section{REFERENCES}

Attalah AM, Johnson RP (1981): A simple, highly sensitive method for the determination of cell viability using an electronic particle analyzer, Coulter counter. J Immunol Methods 41:155-162.

Baur H, Kasperek S, Pfaff E (1975): Criteria of viability of isolated liver cells. Hoppe-Seylers Z Physiol Chem 356:827-838.

Booher J, Sensenbrenner M (1972): Growth and cultivation of dissociated neurons and glial cells from embryonic chick, rat and human brain in flask cultures. Neurobiology 2:97-105.

Bullaro JC, Brookman DH (1976): Comparison of skeleton muscle monolayer cultures initiated with cells dissociated by the vortex and trypsin methods. In Vitro 12:564-570.

Cullen EI, Medzihradsky F (1980): Concurrent isolation of granulocytes and lymphocytes with unaltered permeability, energy state and metabolic capacity in vitro. Biochem Med 23:133-143.

Cummins CJ, Glover RA (1978): Propagation and histological characterization of a homotypic population of astrocytes derived from neonatal rat brain. J Anat 125:117-125.

Gill TH, Young OMM, Tower DB (1974): The uptake of ${ }^{36} \mathrm{Cl}$ into astrocytes in tissue culture by a potassium-dependent, saturable process. J Neurochem 23:1011-1018.

Hanks JH, Wallace JH (1958): Determination of cell viability. Proc Soc Exp Biol Med 98: 188-192.

Hertz L, Schousbe A, Boechler N, Mukerji S, Fedoroff S (1978): Kinetic characteristics of the glutamate uptake in normal astrocytes in cultures. Neurochem Res 3:1-14.

Humason GL (1967): “Animal Tissue Techniques." San Francisco: W.H. Freeman and Co., pp 212 214.

Katzman R (1981): Blood-Brain-CSF-Barriers. In Siegel GJ, Albers JW, Katzman R, Agranoff BW (eds): "Basic Neurochemistry." Boston: Little, Brown and Co., pp 497-510.

Kempski O, Chaussy L, Gross U, Zimmer M, Baethmann A (1983): Volume regulation and metabolism of suspended $\mathrm{C} 6$ glioma cells: An in vitro model to study cytotoxic brain edema. Brain Res 279:217-228. 
Lalande ME, Ling V, Miller RG (1981): Hoechst 33342 dye uptake as a probe of membrane permeability changes in mammalian cells. Proc Natl Acad Sci USA 78:363-367.

Lees MB, Shein HM (1970): Sodium and potassium content of normal and neoplastic rodent astrocytes in cell culture. Brain Res 23:280-283.

Lowry OH, Rosebrough NA, Farr AL, Randall RJ (1951): Protein measurement with the Folin phenol reagent. J Biol Chem 193:265-275.

Malinin TI, Perry VP (1967): A review of tissue and organ viability assay. Cryobiology 4:104-115.

Marangos PJ, Zis AP, Clark RL, Goodwin FK (1978): Neuronal, non-neuronal and hybrid forms of enolase in brain: Structural, immunological and functional comparisons. Brain Res 150:117-133.

Marangos PJ, Schmechel DE, Farma AM, Goodwin FK (1980): Developmental profile of neuronspecific (NSE) and nonneuronal (NNE) enolase. Brain Res 190: 185-193.

McCarthy KD, deVellis J (1980): Preparation of separate astroglial and oligodendroglial cell cultures from rat cerebral tissue. J Cell Biol 85:890-902.

Medzihradsky F (1979): Structure and function of cell membranes, and cellular transport of drugs. In Colombetti LG (ed): "Principles of Radiopharmacology." Boca Raton: CRC Press, pp 197-223.

Medzihradsky F (1982): Transmembrane transport as the rate-limiting phenomenon in the distribution of pharmacological agents. Colombetti LG (ed): "Biological Transport of Radiotracers." Boca Raton: CRC Press, pp 37-48.

Medzihradsky F, Marks MJ (1975): Measures of viability in isolated cells. Biochem Med 13:164-177.

Medzihradsky F, Marks MJ, Metcalfe JI (1974): A simple procedure for the separation of viable blood cells, suitable for long-term in vitro experiments. Biochem Med 10:153-166.

Medzihradsky F, Metcalfe JI (1975): Concurrent separation of plasma and of viable blood cells. J Lab Clin Med 85:342-350.

Medzihradsky F, Nandhasri I, Idoyaga-Vargas V, Sellinger OZ (1971): A comparison of the ATPase activity of the glial cell fraction and the neuronal perikaryal fraction isolated in bulk from rat cerebral cortex. J Neurochem 18:1599-1603.

Patterson MK Jr (1979): Measurement of growth and viability in cells in culture. In Jacoby WB, Pastan IH (eds): "Methods in Enzymology," Vol. 58. New York: Academic Press, pp 141-151.

Peterson GL (1979): Review of the Folin phenol protein quantitation method of Lowry, Rosebrough, Farr, and Randall. Anal Biochem 100:201-220.

Prohaska JR, Clark DA, Wells WW (1973): Improved rapidity and precision in the determination of brain 2', 3'-cyclic nucleotide $3^{\prime}$-phosphohydrolase. Anal Biochem 56:275-282.

Scarna H, Keller A, Pujol FJ (1980): Micromethode de mesure des trois isoenzymes cerebrales de l'enolase. CR Acad Sci [D] Paris 291:397-400.

Schmechel E, Marangos PJ, Brightman M, Goodwin FK (1978): Brain enolases as specific markers of neuronal and glial cells. Science 199:313-315.

Thelestam M, Mollby R (1980): Screening and characterization of membrane damaging effects in tissue culture. Toxicology 17:189-193.

Thompson SW, Hunt RD (1966): "Selected Histochemical and Histopathological Methods." Springfield: C.C. Thomas, pp 813-821.

Walz W, Hertz L (1983): Intracellular ion changes of astrocytes in response to extracellular potassium. J Neurosci Res 10:411-423.

Yavin E, Yavin Z (1974): Attachment and culture of dissociated cells from rat embryo cerebral hemispheres on polylysine-coated surface. J Cell Biol 62:540-546.

Yavin E, Yavin Z (1980): Survival and maturation of cerebral neurons on poly(L-lysine) surfaces in the absence of serum. Dev Biol 75:454-459.

Yavin E, Yavin Z, Habig WH, Hardegree MC, Kohn LD (1981): Tetanus toxin association with developing neuronal cell cultures. J Biol Chem 256:7014-7022. 